\title{
Hubungan Adversity quotient dan Dukungan Sosial dengan Optimisme Akademik pada Siswa SMP Negeri 1 Wanadadi
}

\author{
Ita Anindya Wardani \\ Universitas Negeri Semarang, Semarang, Indonesia \\ itaanindya18@gmail.com \\ Dwi Yuwono Puji Sugiharto \\ Universitas Negeri Semarang, Semarang, Indonesia \\ dypsugiharto@mail.unnes.ac.id
}

\begin{abstract}
Abstrak
Penelitian ini bertujuan untuk mengetahui hubungan antara adversity quotient dan dukungan sosial dengan optimisme akademik pada siswa SMP Negeri 1 Wanadadi. Penelitian ini menggunakan metode penelitian kuantitatif. Subyek penelitian berjumlah 234 siswa SMP Negeri 1 Wanadadi. Instrumen penelitian yang digunakan dalam penelitian ini adalah skala adversity quotient, dukungan sosial dan optimisme akademik. Analisis yang dilakukan dalam penelitian ini adalah korelasi product moment. Hasil analisis data menunjukkan nilai koefisien korelasi sebesar 0,692 dengan taraf signifikansi sebesar $0,000(\mathrm{p}<0,05)$ artinya terdapat hubungan antara variabel adversity quotient dan dukungan sosial dengan optimisme akademik dimana hubungan antar variabel adalah searah. Artinya semakin tinggi adversity quotient dan dukungan sosial maka semakin tinggi pula optimisme akademik.
\end{abstract}

Kata Kunci : Optimisme Akademik, Adversity Quotient, Dukungan Sosial

\section{Abstract}

The Relationship Between Adversity Quotient and Social Support with Academic Optimism for Students of SMP Negeri 1 Wanadadi. The porpose of this research was to examine the relationship of adversity quotient and social support with academic optimism of junior 
high school 1 Wanadadi. This research used quantitative research methods. The research subjects were 234 students of junior high school 1 Wanadadi. The data were collected using learning academic optimism scale, adversity quotient scale and social support scale. The data were analyzed using product moment correlation. The result showed the value of correlation coefficient of 0,479 with a probability level of $0,000(p<0,05)$ it's meaning that there is a significant relation adversity quotient and social support with academic optimism of junior high school 1 Wanadadi. Positive value indicates the higher adversity quotient and social support, the higher the academic optimism.

Keyword: Academic Optimism, Adversity Quotient, Social Support

\section{A. Pendahuluan}

Siswa pada Sekolah Menengah Pertama (SMP) dapat digolongkan dalam perkembangan masa remaja. Erikson (Santrock 2007) menjelaskan bahwa perkembangan remaja berada pada tahap kelima yang ditandai adanya kecenderungan identity vs identity confusion, dimana pada tahap ini remaja mengalami proses perkembangan identitas versus kebingungan identitas. Dimana pada tahap ini remaja mengalami proses perkembangan identitas versus kebingungan identitas seperti tantangan untuk menemukan siapa dirinya, langkah apa yang akan diambil serta masa depan seperti apa yang ingin diraih. Jika individu dapat menjalani berbagai peran baru dengan positif maka identitas yang positif juga akan tercapai. Akan tetapi jika individu kurang mendapat bimbingan dan mendapat banyak penolakan terkait berbagai perannya, maka ia bisa jadi akan mengalami kebingungan identitas. Pada hakikatnya siswa yang mampu berkembang dengan baik pada tahap ini mampu menunjukan sikap optimis dan memiliki keyakinan yang tinggi dan tidak mudah menyerah dalam meraih apa yang dicita-citakan. Siswa akan memiliki pandangan yang positif pada setiap permasalahan yang dihadapi. Secara tidak sadar adanya tekanan sosial dan akademik yang dialami siswa seringkali mendorong remaja menuntut tanggung jawab yang lebih besar untuk melakukan peran baru yang harus dikerjakan. Misalnya tekanan untuk naik kelas, lamanya belajar, mencontek, banyak tugas, 
rendahnya prestasi yang diperoleh serta kecemasan saat menghadapi ujian (Rahmawati 2017). Siswa kurang optimis dapat dikenali dari Gejala ini yaitu, dengan munculnya perilaku ketidakaktifan siswa di dalam kelas. Siswa yang sebenarnya mampu menjawab dengan baik tugas maupun ujian yang diberikan guru. Siswa merasa tidak percaya diri terhadap kemampuan yang dimiliki, sehingga membutuhkan bantuan orang lain untuk menyelesaikan tugas yang diberikan oleh guru. Siswa tidak berani menyampaikan pendapat di kelas dan tampil dimuka, sehingga cenderung pasif dikelas. Siswa yang kurnag memiiki keoptimisan untuk bersaing meraih prestasi akademik (Dawama 2018).

Menurunnya sikap optimis siswa dalam bidang akademik berdampak pada keberhasilan siswa itu sendiri. Siswa yang cenderung pesimis akan sulit menggali potensi dirinya dan tidak memiliki semangat dalam menggapai cita-cita. Seorang siswa yang memiliki kecerdasaan intelektual yang tinggi, namun tidak memiliki optimisme dalam dirinya untuk mencapai keberhasilan akademik, maka prestasi akademik yang diraih akan kurang memuaskan. Siswa yang pesimis dalam belajar membutuhkan penanganan yang lebih untuk menyelesaikan permasalahan sikap optimis siswa yang rendah (Dawama 2018). Namun dampak tersebut dapat diatasi apabila siswa memiliki optimisme dalam akademik dan sekolah. Seligman (2002, 376) menjelaskan bahwa optimisme dapat meningkatkan prestasi dibandingkan dengan remaja yang cenderung pesimis. Optimisme merupakan sebuah explanatory style yang digunakan seseorang untuk menjelaskan peristiwaperistiwa negatif berasal dari lingkungan (eksternal) bersifat sementara dan memiliki sebab yang spesifik. Akademik didefinisikan sebagai sesuatu yang berhubungan dengan akademik yang bersifat ilmiah, bersifat ilmu pengetahuan, bersifat teori, dan tanpa arti praktis yang langsung (Departemen Pendidikan Nasional, 2005: 308).

Optimisme akademik merupakan sebuah explanatory style yang digunakan individu untuk menjelaskan harpan mengenai keberhasilan akademik di masa 
yang akan datang yang menyebabkan individu memiliki keyakinan pada kemampuan untuk melakukan perubahan menuju kesuksesan. Nurmayasri, Hadjam dan Nurmayasari (2015) menjelaskan bahwa siswa yang memiliki keyakinan positif akan memiliki harapan yang positif pula untuk menghadapi tantangan dan hambatan termasuk dalam mengerjakan ujian atau tugas di sekolah. Harapan positif yang dimiliki oleh individu akan mengarahkan perilakunya dengan memusatkan perhatian pada kesuksesan, optimis, pemecahan masalah yang menjauhkan diri dari perasaan takut akan kegagalan dengan menggunakan katakata yang mengandung harapan. Sikap optimisme pada siswa akan sangat membantu dalam proses pembelajaran. Siswa optimis akan menanggap kegagalan terjadi karena faktor di luar dirinya, sehingga memacu dirinya untuk mengatasi dan memperbaiki hingga faktor penyebab kegagalan tersebut lenyap dari dirinya. Sikap seperti inilah yang sangat dibutuhkan siswa untuk meningkatkan kemampuannya dala usaha mencapai cita-citanya (Kurniati and Umar, Fakhruddin 2018).

Menurut Carver \& Scheier (2009) individu yang optimis cenderung merasa yakin dan gigih dalam menghadapi tuntutan walaupun mengalami kesulitan Kemampuan individu untuk dapat berhadapan dengan situasi yang tidak menguntungkan atau tidak menyenangkan maupun kesulitan dalam kehidupan disebut adversity quotient (Stoltz 2000). Konsep ini muncul dikarenakan konsep IQ (Intelligence quotient) yang menggambarkan tingkat kecerdasan individu dan EQ (Emotional Quotient) yang menggambarkan aspek afektif dan keefektifan dalam berinteraksi dengan orang lain Golerman dalam (Stoltz 2000), dianggap kurang dapat memprediksi keberhasilan orang. Individu yang cerdas dibidang akademik dan baik secara emosional terkadang tidak mendapatkan kesuksesan dalam hidupnya karena mereka pesimis dan diam ketika dihadapkan pada kesulitan dan kegagalan dan akhirnya mereka berhenti berusaha dan menyia-nyiakan kemampuan Intelligence Quotient dan Emotional Quotient yang dimilikinya (Stoltz, 2000). Stoltz (2000) menyebutkan kesuksesan dipengaruhi oleh kepercayaan akan 
hasil positif yang akan terjadi dikehidupannya sendiri. Kesuksesan sangat dipengaruhi dan dapat diramalkan melalui cara seseorang merespon dan menjelaskan kesulitan. Menurut Stoltz (2000) individu dengan adversitas tinggi akan lebih mempunyai kemampuan yang luar biasa untuk dapat menaruh harapan dan optimis untuk melalui situasi sulit yang berlangsung. Sebaliknya, individu dengan adversitas rendah akan memandang bahwa situasi sulit berlangsung secara lama dan berangsur-angsur. Berdasarkan penelitian Muslimah dan Yohana (2019) terdapat hubungan optimisme dengan adversity quotient, artinya semakin tinggi optimisme yang dimiliki siswa maka semikin tinggi pula adversity quotient.

Terbentuknya pola pikir optimis tergantung juga pada cara pandang seseorang pada perasaan dirinya bernilai atau tidak. Perasaan bernilai dan berarti biasanya tumbuh dari pengakuan oleh lingkungan. Optimisme yang tinggi yang berasal dari dalam diri individu dan dukungan berupa penghargaan dari orangorang tertentu membuat individu merasa dihargai dan berarti. Menurut Indarhadi (2017) faktor-faktor yang muncul pada optimisme siswa yaitu faktor internal berupa motivasi, harapan, keyakinan, religiusistas dan emosi. Sedangkan faktor eksternal yaitu berupa dukungan keluarga, teman dan guru, serta suasana belajar juga mempengaruhi untuk menumbuhkan optimisme. Berdasarkan hasil penelitian Rachmawaty (2016) dukungan sosial guru mempunyai hubungan yang positif dengan optimisme akademik. Semakin tinggi dukungan sosial guru, maka semakin tinggi optimisme akademik siswa. Lebih lanjut, Carver, dkk (2009: 131) menyatakan bahwa dukungan sosial mampu mengembangkan optimisme dalam diri seorang individu. Saat individu dapat merasakan dukungan dari orang-orang, dia akan lebih yakin untuk dapat bertahan dalam situasi-situasi sulit. Dukungan sosial yang diterima dapat membuat individu merasa tenang, diperhatikan, dicintai, timbul rasa percaya diri dan kompeten (Kumalasari \& Latifah, 2012: 25). Orang yang prcaya terhadap lingkungan ditandai dengan sikap optimis, berpikir positif, percaya diri, dan yakin dapat melaukan sesuatu di masa depan. 
Berdasarkan studi pendahuluan yang dilakukan pada tanggal 16 April 2019 kepada siswa kelas VII F, di dapatkan hasil bahwa rata-rata optimisme akademik. Pengamatan awal yang dilakukan kepada 29 siswa kelas VIII F menghasilkan 2 siswa memiliki optimisme tinggi (78,64 \%), 23 siswa memiliki optimisme sedang $66,53 \%$, dan 4 siswa memiliki optimism rendah (35,67\%). Dapat diketahui bahwa presentase rata-rata optimisme akademik siswa kelas VII F adalah 63, 11 \%. Hasil wawancara dengan salah satu guru Bimbingan dan Konseling di SMP Negeri 1 Wanadadi, terkait optimisme akademik siswa di SMP Negeri 1 Wanadadi rata-rata siswa memiliki optimisme yang baik dan perlu ditingkatkan. Namun ada beberapa siswa yang memiliki nilai dibawah KKM yang memiliki optimisme rendah. Guru merasa bahwa permasalahan akademik dengan nilai yang kurang baik ini berasaal dari siswa sendiri dengan berbagai permasalahannya. Guru merasa telah mempersiapkan siswanya dengan baik dengan segenap kemampuannya. Guru mengakui bahwa belum memberikan pendampingan khusus bagi siswa yang memiliki nilai kurang baik. Berdasarkan latar belakang tersebut, maka peneliti disini bermaksud akan meneliti tentang "Hubungan adversity quotient dan dukungan sosial dengan optimisme akademik siswa SMP Negeri 1 Wanadadi”.

\section{B. Pembahasan}

\section{Optimisme Akademik}

a. Definisi Optimisme Akademik

Seligman (2002: 376) menjelaskan bahwa optimisme dapat meningkatkan prestasi dibandingkan dengan remaja yang cenderung pesimis. Optimisme merupakan sebuah explanatory style yang digunakan seseorang untuk menjelaskan peristiwa-peristiwa negatif berasal dari lingkungan (eksternal) bersifat sementara dan memiliki sebab yang spesifik. Seligman dalam Carr (2004: 85) Optimisme menjelaskan peristiwa positif ke dalam pribadi dan menetap hingga akhirnya terinternalisasi. Akademik didefinisikan sebagai sesuatu yang berhubungan dengan akademik yang bersifat ilmiah, bersifat 
ilmu pengetahuan, bersifat teori, dan tanpa arti praktis yang langsung (Departemen Pendidikan Nasional, 2005: 301). Optimisme akademik merupakan sebuah explanatory style yang digunakan individu untuk menjelaskan harpan mengenai keberhasilan akademik di masa yang akan datang yang menyebabkan individu memiliki keyakinan pada kemampuan untuk melakukan perubahan menuju kesuksesan.

b. Aspek Optimisme

Menurut Seligman (2002) menjelaskan ada tiga dimensi cara menerangkan suatu peristiwa baik atau buruk tejadi untuk mengetahui individu tersebut pesimis atau optimis, yaitu:

Pertama adalah Permanance, yaitu individu yang pesimis dengan mudah mempercayai penyebab dari berbagai kejadian buruk yang terjadi pada mereka secara permanen. Kedua adalah Pervasiveness, yaitu menerangkan bagaimana pengaruh peristiwa yang dialami terhadap suatu situasi yang berada dalam hidup baik secara spesifik atau universal. Ketiga adalah Perzonalization, yaitu baik secara internal atau eksternal, individu dapat menjelaskan apa yang menjadi penyebab suatu peristiwa baik itu berasal dari diri sendiri (internal) atau orang lain (eksternal).

\section{Adversity quotient}

a. Definisi Adversity quotient

Menurut Stoltz (2000) Adversity quotient dijelaskan sebagai kemampuan individu untuk menghadapi permasalahan sehingga tidak akan mempengaruhi kehidupannya. Menurut Shabrina (2018) Adversity quotient adalah suatu kemampuan individu untuk dapat bertahan dari kesulitan dan mengubah hal tersebut menjadi peluang untuk mencapai kesuksesan. Berdasarkan uraian tersebut dapat disimpulan bahwa adversity quotient adalah kemampuan individu dalam menghadapi masalah atau kesulitan menjadi suatu proses untuk mengembangkan diri, potensi-potensi, dan untuk mencapai tujuan hidup yang lebih berkualitas. 


\section{b. Dimensi-dimensi Adversity quotient}

Berdasarkan teori kecerdasan adversitas dari Stoltz (2000), terdapat 4 dimensi yang lebih dikenal dengan singkatan CO2RE, diantaranya : Pertama adalah Control atau kendali bertujuan untuk mengetahui sejauh mana atau seberapa besar kendali yang dilakukan oleh individu terhadap keadaan yang menyulitkan. Kedua adalah 02 (Origin dan Ownership). Origin adalah yang mempertanyakan apa atau siapa yang menimbulkan kesulitan, sedangkan Ownership bertujuan untuk mempertanyakan sejauh mana individu bersedia mengakui akibat-akibat yang ditimbulkan dari situasi yang menyulitkan. Ketiga adalah Reach, dimensi inimempertanyakan sejauh mana kesulitan yang dihadapi akan mempengaruhi bagian atai sisi lain dari kehidupan individu. Keempat adalah Endurance, dimensi ini mempunyai makna sebagai ketahanan dalam arti akan mempertanyakan berapa lama situasi sulit akan berlangsung. Berdasarkan uraian tersebut dapat diketahui dimensi-dimensi adversity quotient meliputi control (kendali), origin dan ownership (asal usul dan pengakuan), reach (jangkauan), dan endurance (daya tahan). Dimensi-dimensi inila yang nantinya akan digunakan sebagai pedoman pengembangan alat ukur adversity quotient pada siswa.

\section{Dukungan Sosial}

\section{a. Definisi Dukungan Sosial}

Menurut Baron dan Byrne (2015) menyatakan bahwa dukungan sosial merupakan kenyamanan secara fisik dan psikologis yang diberikan oleh teman atau keluarga.Dukungan Sosial merupakan pertukaran hubungan antar pribadi yang bersifat timbal balik dimana seseorang memberi bantuan kepada orang lain.

Sedangkan menurut Smet (Usfuriyah 2015) mengatakan bahwa dukungan sosial merupakan salah satu fungsi dari ikatan sosial, dan ikatan-ikatan sosial tersebut menggambarkan tingkat kualitas umum dari hubungan interpersonal. Ikatan dan persahabatan dengan orang lain dianggap sebagai aspek yang 
memberikan kepuasan secara emosional dalam kehidupan individu. Saat seseorang didukung oleh lingkungan maka segalanya akan terasa lebih mudah. Dukungan sosial menunjukkan pada hubungan interpersonal yang melindungi individu terhadap konsekuensi negatif dari stres. Dukungan sosial yang diterima dapat membuat individu merasa tenang, diperhatikan, dicintai, timbul rasa percaya diri dan kompeten (Kumalasari and Latifah 2012)

Berdasarkan uraian tersebut disimpulkan bahwa dukungan sosial adalah dukungan yang diberikan oleh orang lain berupa infomasi, emosional, instrumental dan penghargaan yang membuat individu merasa tenang, diperhatikan, dicintai, timbul rasa percaya diri dn kompeten.

b. Tipe Dukungan Sosial

Menurut Sarinoo (Kumalasari and Latifah 2012) dukungan sosial terdiri dari empat dimensi yaitu:

Pertama adalah dukungan emosional, dukungan ini melibatkan ekspresi rasa empati dan perhatian terhadap individu, sehingga indvidu tersebut merasa nyaman, dicintai dan diperhatikan. Dukunan ini meliputi perilaku seperti memberikan perhatian dan afeksi serta bersedia mendengarkan keluh kesah orang lain. Kedua adalah Dukungan penghargaan, dukungan ini melibatkan eskpresi yang beruapa pernyataan setuju dan penilaian positif teradap ide-ide, perassaan dan perfoma orang lain. Ketiga adalah Dukungan instrumental, dukungan ini melibatkan bantuan langsung, misalnya berupa bantua finansial atau bantuan dalam mengerjakan tugas-tugas tertentu. Keempat adalah Dukungan informasi, dukungan yang bersifat informasi dapat berupa saran, pengarahan dan umpan balik tentang bagaimana cara memecahkan persoalan. Kelima adalah Dukungan Jaringan sosial, dukungan ini yang dimiliki individu dengan orang-orang dalam keluarga dan lingkungan

Dari penjelasan bebrapa tokoh diatas maka dapat disimpulkan bahwa dimensi-dimensi dukungan sosial meliputi dukungan emosional, dukungan 
penghargaan, dukungan instrumental, dan dukungan informatif dan dukungan jaringan sosial.

\section{Metode penelitian}

Penelitian ini menggunakan jenis penelitian kuantitatif. Berdasarkan analisis data, peneltian ini menggunakan analisis regresi berganda untuk mengetahui hubungan advesity quotient dan dukungan sosial dengan optimisme akademik.

Penelitian ini dilakukan di SMP Negeri 1 Wanadadi yang beralamat di Jl. Raya Timur Wanadadi, Banjarnegara, Jawa Tengah. Populasi dalam penelitian ini berjumlah 690 siswa. Sampel dalam penelitian ini adalah sejumlah 234 siswa dengan teknik sampling stratified random sampling. Teknik ini merupakan teknik pengambilan anggota sampel dari populasi dengan memperhatikan strata (tingkatan) di dalam populasi (Sugiyono 2016).

Instrumen penelitian yang digunakan dalam penelitian ini menggunakan skala Likert. Skala ini digunakan untuk mengukur tiga variabel yang ada dalam penelitian. Metode pengumpulan data yang digunakan dalam penelitian ini berupa skala optimisme akademik, skala adversity quotient dan skala dukungan sosial. Uji validitas yang akan digunakan dalam penelitian ini yaitu validitas konstruk (construct validity). Realibilitas instrumen yang digunakan dalam penelitian ini adalah internal consistency.

Teknik statistik yang digunakan dalam penelitian ini adalah uji asumsi dan uji hipotesis, uji asumsi terdiri dari uji normalitas, uji linearitas, uji multikolinearitas dan uji heterokedastisitas.pengujian ini digunakan bantuan program pengolahan data S,PSS 21.0 for windows,

Teknik analisis data yang digunakan pada penelitian ini adalah analisis data deskriptif dan teknik regresi berganda. Analisis data deskriptif digunakan untuk mengetahui tingkatan ketiga variabel, sedangkan teknik regresi berganda dalam penelitian ini digunakan untuk mengetahui hubungan antar variabel bebas dan variabel terikat. 


\section{Hasil penelitian}

a. Hasil analisis deskritif

Deskripsi data ini menganalisis tingkat optimisme akademik, adversity quotient dan dukungan sosial sesuai aspek ataupun indikator pada masingmasing variabel Berikut data disajikan dalam gambar 1.

Gambar 1. Hasil deskripsif data

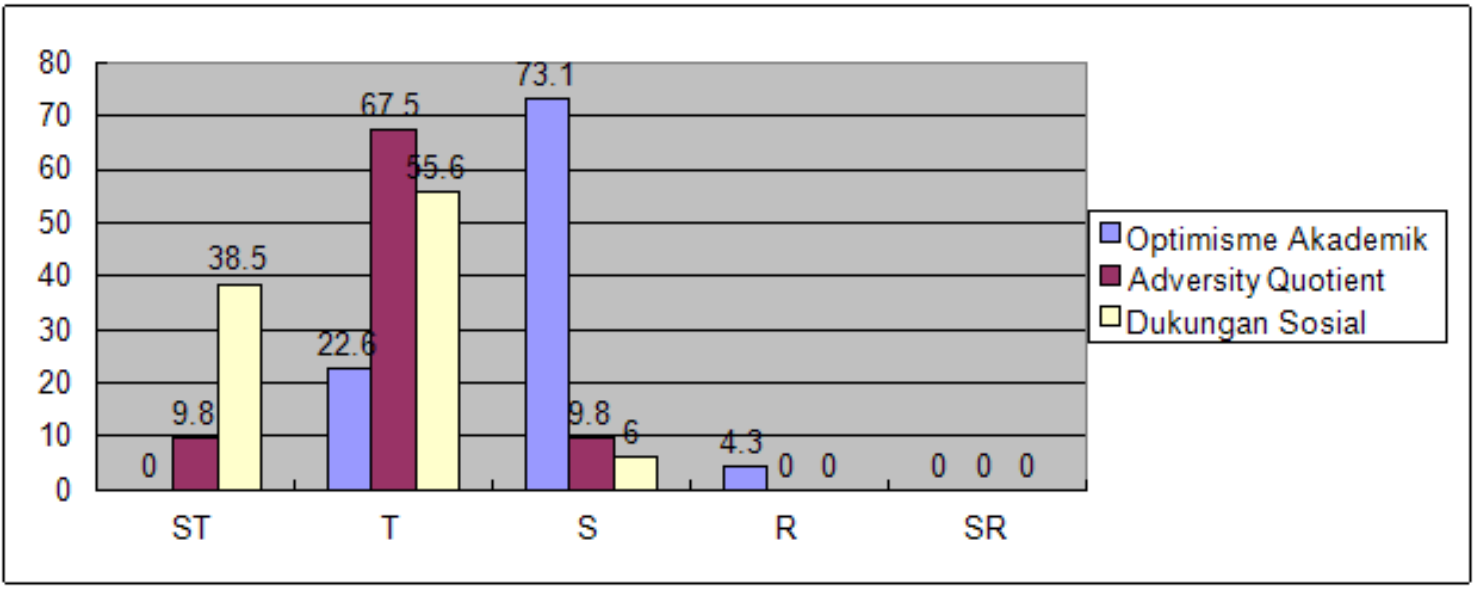

Berdasarkan gambar 1 kecenderungan terbesar tingkat optimisme akademik siswa SMP Negeri 1 Wanadadi termasuk dalam kategori sedang. Dengan kategori sangat rendah sebesar $0 \%$, kategori rendah sebesar 4,3\% dengan jumlah sebanyak 10 siswa, kategori sedang sebesar 73,1 \% dengan jumlah sebanyak 171 siswa, kategori tinggi sebesar 22,6 \% dengan jumlah sebanyak 53 siswa dan kategori sangat tinggi sebesar $0 \%$.

Berdasarkan gambar 1 kecenderungan terbesar tingkat adversity quotient siswa SMP Negeri 1 Wanadadi termasuk dalam kategori tinggi. Dengan kategori sangat rendah sebesar $0 \%$, kategori rendah sebesar $0 \%$, kategori sedang sebesar 9,8 \% dengan jumlah sebanyak 23 siswa, kategori tinggi sebesar 67,5 \% dengan jumlah sebanyak 158 siswa dan kategori sangat tinggi sebesar 9,8 \% dengan jumlah sebanyak 23 siswa.

Berdasarkan gambar 1 kecenderungan terbesar tingkat dukungan sosial siswa SMP Negeri 1 Wanadadi termasuk dalam kategori tinggi. Dengan 
kategori sangat rendah sebesar $0 \%$, kategori rendah sebesar $0 \%$, kategori sedang sebesar 6,0 \% dengan jumlah sebanyak 14 siswa, kategori tinggi sebesar 55,6 \% dengan jumlah sebanyak 130 siswa dan kategori sangat tinggi sebesar 38,5 \% dengan jumlah sebanyak 90 siswa.

1) Hasil uji asumsi klasik

Hasil dari uji asumsi klasik dengan menggunakan uji kolmogrov-smirnov untuk variabel optimisme akademik, adversity quotient dan dukugnan sosial, sebagai berikut:

Tabel 1 Hasil uji distribusi normal

\begin{tabular}{lllll}
\hline Uji Asumsi Klasik & Variabel & Parameter & $\begin{array}{l}\text { Sig } \\
(\mathrm{p})\end{array}$ & Keterangan \\
\hline Uji Normalitas & OA & K-S $=0,629$ & 0,823 & Normal \\
& AQ & K- S =0,931 & 0,351 & Normal \\
Uji Linearitas & DS & K-S $=0,542$ & 0,930 & Normal \\
& AQ & F =222, 369 & 0,000 & Linear \\
Uji & DS & F =61,693 & 0,000 & Linear \\
Multikolinearitas & AQ \& DS & Torelance & $=$ & Bebas \\
Uji Heterokedastis & AQ & 0,728 & & Multikolinearitas \\
& & VIF $=1,373$ & & \\
& DS & 0,021 & 0,476 & Tidak \\
& & & & Heterokedastisitas \\
& & & 0,079 & Tidak \\
\hline
\end{tabular}

Berdasarkan tabel 1 hasil uji normalitas dapat diketahui bahwa nilai signifikansi dari variabel optimisme akademik sebesar 0,823, adversity quotient sebesar 0,351 dan dukungan sosial sebesar 0,930. Sehingga dapat disimpulkan bahwa ketiga variabel memiliki sebaran data normal karena nilai signifikansi variabel tersebut $>0,05$. Hasil uji linearitas terlihat bahwa variabel optimisme akademik dengan adversity quotient diperoleh nilai signifikansi <0,05 sehingga dinyatakan linear. Begitu pula antara variabel optimisme akademik dengan dukungan sosial juga memiliki ubungan yang linear karena nilai signifikansi yang diperoleh $<0,05$. Skor Torelance sebesar dan skor VIF sebesar untuk semua 
prediktor. Skor Tolerance 0,728 > 0,1 dan skor VIF 1,373< 10 sehingga dapat disimpulkan bahwa uji asumsi multikolinearitas telah terpenuhi. Sedangkan hasil uji heterokedastisitas terlihat bahwa nilai signifikansi pada variabel adversity quotient sebesar 0,476 dan nilai signifikansi pada variabel dukungan sosial sebesar 0,079. Karena nilai signifikansi lebih dari 0,05 maka dapat disimpulkan bahwa uji asumsi heterokedastisitas telah terpenuhi.

b. Hasil Analisis Regresi Berganda

\begin{tabular}{lllll}
\hline Prediktor & & $\mathrm{R}$ & $\mathrm{R} 2$ & $\mathrm{Sig}$ \\
\hline Adversity quotient & $\&$ & 0,692 & 0,479 & 0,000 \\
Dukungan Sosial & & & &
\end{tabular}

Tabel 3 Ringkasan hasil uji regresi ganda

Berdasarkan tabel 3 menunjukkan bahwa a adversity quotient dan dukungan sosial dengan optimisme akademik terdapat hubungan yang signifikan $(R=0,692, p<0,05$ dan koefisien determinasi sebesar 0, 479 yang menginformasikan bahwa presentase sumbangan adversity quotient dan dukungan sosial dalam menjelaskan optimisme akademik adalah sebesar 47,9 $\%$.

\section{Pembahasan}

Dari hasil analisis data yang diperoleh nilai sig $0,000<\alpha 0,05$, maka Ho ditolak dan Ha diterima. Hal ini berarti adversity quotient dan dukungan sosial berhubungan signifikan dengan optimisme akademik pada siswa SMP Negeri 1 Wanadadi. Hasil analisis data menunjukkan bahwa semakin tinggi adversity quotient dan dukungan sosial maka optimisme akademik siswa juga semakin tinggi.

Siswa yang dengan adversity quotient yang baik memiliki tujuan untuk mengetahui apa yang harus dilakukan ketika dalam situasi sulit, untuk 
menempatkan sesuatu yang menjadi sumber kesulitannya kepada orang lain atau lingkungan, untuk mencerminkan sikap dan tanggung jawab yang lebih tinggi dari situasi sulitnya tanpa menghiraukan penyebabnya, untuk mengerahkan perhatian pada kesulitan yang dihadapi serta untuk dapat menaruh harpan dan optimis untuk situasi sulit yang akan berlangsung (Stoltz 2000). Selain itu, optimisme akademik yang dimiliki siswa berpengaruh pada pola perilaku sehari-hari.

Hal ini relevan dengan penelitian Utami, Harjono Kurniawan (2014) yang mana kesimpulan dari penelitian tersebut adalah optimisme dan adversity quotient memiliki hubungan positif signifikan. Dengan kata lain hubungan positif ini menunjukkan bahwa semakin tinggi adversity quotient maka semakin tinggi pula optimisme sehingga tingkat adversity quotient yang tinggi pada individu dapat meningkatkan optimisme. Sejalan dengan penelitian yang dilakukan oleh Muslimah \& Yohana (2019) menjelaskan bahwa optimisme dan adversity quotient memiliki hubungan positif signifikan, adversity quotient yang cukup akan membantu siswa dalam menghadapi berbagai kondisi sulit sehingga tidak mudah menyerah dalam menghadapinya dan hal itu membutuhkan optimisme dimana siswa memiliki keyakinan terhada hal baik yang akan terjadi di masa depan dalam kaitanya dengan berbagai tugas dan tujuan yang hendak di capai.

Mengacu pada penelitian M. Immanuel (2017) menjelaskan bahwa optimisme akademik dan adversity quotient memiliki hubungan positif signifikan, dapat disimpulkan siswa yang memiliki keyakinan diri baik tentang diri mereka sendiri terkait dengan kegiatan akademiknya, terhadap guru sekolah mereka, maupun terhadap dukungan dan juga tekanan orang tua mereka dalam hal akademik dapat dipengaruhi oleh sikap dalam menghadapi masalah dan tantangan serta membantu siswa untuk mencapai hasil yang baik dalam hal akademik siswa.

Siswa membutuhkan dukungan sosial yang positif untuk mendukung siswa dalam berinteraksi sosial dan membuat dirinya merasa dihargai, memiliki perasaan positif, serta pandangan hidup yang lebih baik. Dukungan sosial dapat mengubah penilaian kognitif seseorang atas suatu peristiwa, meningkatkan harga 
diri, mengurangi kecemasan, meningkatkan kemampuan memecahkan masalah atau memfasilitasi perubahan perilaku (Cohen, Underwood, and Gottlieb 2000). Kondisi ini dapat membuat siswa dapat meningkatkan optimisme akademik dengan lebih yakin untuk dapat bertahan dalam situasi-situasi sulit, dan optimisme terbentuk melalui individu mengenai apakah dirinya bernilai atau tidak (Carver \& Scheier, 2009: 121).

Hal ini sejalan dengan hasil penelitian Hasan dkk., (2011), dapat disimpulkan bahwa dukungan sosial sangat berhubungan dengan optimisme. Adanya keyakinan akan diri sendiri dapat dibantu dengan dukungan dari orang lain yang akan memperkuat keyakinnan tersebut. Sama halnya dengan peneltian yang dilakukan oleh Rachmawati (2016) yang meneliti tentang hubungan dukungan sosial guru dengan optimisme akademik menyatakan bahwa dukungn sosial guru mempunyai hubungan yang positif dengan optimisme akademik, dukungan sosial guru adalah faktor salah satu yang dapat mempengaruhi optimisme akademik siswa.

Mengacu pada penelitian Ushfuriyah (2015) menjelaskan bahwa terdapat hubungan yang signifikan antara dukungan sosial dengan optimisme mahasiswa psikologi dalam menyelesaikan skripsi, dimana arah hubungannya positif. Hal ini menunjukkan bahwa dalam menyelesaikan skripsi mahasiswa sangat membutuhkan dukungan dan lingkungannya supaya mereka tetap mampu bertahan serta berfikir secara positf saat menghadapi kendala yang dihadapi dalam menyelesaikan skripsi.

Berdasarkan penjelasan di atas, maka hal tersebut sesuai dengan hasil penelitian yang menunjukkan bahwa terdapat hubungan antara adversity quotient dan dukungan sosial dengan optimisme akademik. Selanjutnya jika di implikasikan bagi konselor hendaknya memberikan layanan format klasikal berupa penguasaan konten yaitu dengan mengajarkan kepada siswa untuk memiliki adversity quotient yang tinggi. Konselor sekolah hendaknya memberikan layanan bimbingan konseling kepada guru, orang tua dan siswa berupa informasi untuk memberikan dukungan sosial. Misalnya, melalui layanan konsultasi konselor memberikan 
informasi kepada guru mata pelajaran untuk memberikan perhatian dan kenyamanan kepada siswa pada saat mengajar di kelas sehingga siswa akan merasa senang ketika di sekolah. Selanjutya, melalui layanan home visit konselor memberikan informasi kepada orang tua untuk memperhatikan setiap tindakan yang dilakukan, dan mau mendengarkan jika siswa dihadapkan pada suatu masalah sehingga muncul perasaan untuk bersikap terbuka kepada orang tua. Selanjutnya, konselor memberikan layanan informasi klasikal kepada siswa untuk dapat menumbuhkan sikap peduli, memahami perasaan, dan menghargai orang lain, sehingga dengan dukungan emosional yang diperoleh siswa dapat termotivasi untuk mengerjakan tugasnya dan meningkatkan optimisme akademik.

\section{Simpulan}

Berdasarkan hasil penelitian dan pembahasan, kesimpulan yang dapat diambil dari hubungan adversity quotient dan dukungan sosial dengan optimisme akademik adalah sebagai berikut: adversity quotient dan dukungan sosial secara bersama-sama berhubungan signifikan dengan optimisme akademik siswa SMP Negeri 1 Wanadadi. Artinya semakin tinggi adversity quotient dan dukungan sosial, maka semakin tinggi optimisme akademik siswa SMP Negeri 1 Wanadadi, adversity quotient berhubungan signifikan dengan optimisme akademik siswa SMP Negeri 1 Wanadadi. Artinya, semakin tinggi adversity quotient, maka akan semakin tinggi optimisme akademik siswa SMP Negeri 1 Wanadadi, dan dukungan sosial berhubungan signifikan dengan optimisme akademik siswa SMP Negeri 1 Wanadadi. Berarti, semakin tinggi dukungan sosial maka akan semakin tinggi pula optimisme akademik siswa SMP Negeri 1 Wanadadi.

Adapun keterbatasan dalam penelitian ini yaitu : (1) peneliti ini masih berfokus, melihat optimisme akademik dari sisi adversity quotient dan dukungan sosial; (2) Sampel yang digunakan dalam penelitian ini masih berfokus pada siswa SMP Negeri 1 Wanadadi, sehingga hasi penelitian tidak dapat diterapkan dalam 
ruang lingkup yang lebih luas dengan jumlah sampel penleitian yang lebih banyak dan dengan karakteristik yang berbeda.

Saran dari penelitian ini yaitu; (1) Guru Bimbingan dan Konseling hendaknya memberikan layanan format klasikal berupa penguasaan konten yaitu dengan mengajarkan kepada siswa untuk memiliki adversity quotient yang tinggi. Guru Bimbingan dan konseling memberikan layanan informasi klasikal kepada siswa untuk dapat menumbuhkan sikap peduli, memahami perasaan, dan menghargai orang lain, sehingga dengan dukungan emosional yang diperoleh siswa dapat termotivasi untuk mengerjakan tugasnya dan meningkatkan optimisme akademik. (2) Siswa diharapkan dapat meningkatkan adversity quotient agat tidak mudah menyerah ketika mengalami kesulitan. Siswa diharapakan dapat menyadari bahwa dukungan sosial yang diberikan oleh orangtua, guru, teman sebaya memiliki dampak secara psikologis terhadap optimisme akademiknya sehingga lebih dapat memanfaatkan dukungan sosial tersebut. (3) Peneliti selanjutnya diharapkan dapat memberikan masukan yang lebih baik terkait adversity quotient dan dukungan sosial dengan optimisme akademik sehingga hasil yang didapat dapat mendukung peneltian sebelumnya. 


\section{DAFTAR PUSTAKA}

Baron, Philip. 2015. "A Challenge to Objective Perception in Hearing and Seeing in Counselling Psychology." Kybernetes 44(8/9): 1406-18. http://www.emeraldinsight.com/doi/10.1108/K-12-2014-0294.

Carr, A. 2004. Positive Psychology: The Science of Happiness and Human Strengths. New York: Burnner-Routledge.

Carver, C. S., and M. F. Scheier. 2009. Optimism: Handbook of Individual Differences in Social Behavior. New York: APA.

Cohen, S., L.G. Underwood, and B.H Gottlieb. 2000. Social Support Measurement and Intervention. New York: Oxford University Press.

Dawama, Fatin. 2018. "Pengaruh Layanan Bimbingan Dan Konseling Terhadap Optimisme Keberhasilan Belajar Siswa Di MTS Istiqlal Delitua." Universitas Islam Negeri Sumatera Utara.

Departemen Pendidikan Nasional. 2005. Kamus Besar Bahasa Indonesia. Tiga. Jakarta: Balai Pustaka.

Immanuel, M. Anggia. 2017. "Hubungan Antara Optimisme Akademik Dengan Adersity Quotient Pada Siswa SMP." Universitas Kristen Satya Wacana.

Indarhadi, Pradipta Lancana. 2017. "Optimisme Remaja SMP Yang Tidak Berpestasi Akademik." Universitas Muhammadiyah Surakarta.

Kumalasari, F., and N. A. Latifah. 2012. "Hubungan Antara Dukugnan Sosial Dengan Penyesuaian Diri Remaja Di Panti Asuhan." Journal Peneltian 3 (2).

Kurniati, Lenny, and Asef Umar, Fakhruddin. 2018. "PENGARUH OPTIMISME TERHADAP KEMAMPUAN PEMECAHAN MASALAH MATEMATIKA PADA SISWA SMA." In Prosiding Seminar Nasional Dan Internasional, Semarang: Universitas Muhammadiyah Semarang. https://jurnal.unimus.ac.id/index.php/psn12012010/article/view/4113.

Muslimah, Ismei, and W. R. Yohana. 2019. "Hubungan Optimisme Dengan Adversity Quotient Pada Siswa Kelas XI SMA Negeri 2 Pare." Jurnal Penelitian Psikologi $06(1)$.

Nurmayasari, K, and M. Hadjam. 2015. "Hubungan Antara Berpikir Positif Dan Perilaku Menyontek Pada Siswa Kelas X SMK Koperasi Yogyakarta." Empathy: Jurnal Fakultas Psikologi 3, No. 1.

Rachmawaty, Dian Budi. 2016. "Hubungan Antara Dukungan Sosial Guru Dengan Optimisme Akademik Pada Siswa Kelas XI SMA Gita Bahari Semarang." Universitas Negeri Semarang.

Rahmawati, W. K. 2017. "Efektivitas Teknik Restrukturasi Kognitif Untuk Menangani Stres Akademik Siswa." Journal Kounseling Indonesia 2 (1). 
Santrock, John W. 2007. Perkembangan Anak. 11th ed. Jakarta: Erlangga.

Seligman, M. 2002. Authentic Happiness: Using the New Positive Psychology to Realize Your Potential for Lasting Fulfill-Ment. New York: Free Press.

Shabrina, Nur Baeti Ulya. 2018. "Optimisme Dan Adversity Quotient Pada Remaja Panti Asuhan Di Yogyakarta." Universitas Islam Indonesia.

Stoltz, P. G. 2000. Adversity Quotient: Mengubah Hambatan Menjadi Peluang. Jakarta: Grasindo.

Sugiyono. 2016. Metode Penelitian Kuantitatif, Kualitatif, Dan R\& D. Bandung: Alfabeta.

Usfuriyah. 2015. "Hubungan Antara Dukungan Sosial Dengan Optimisme Mahasiswa Psikologi UIN Maulana Malik Ibrahim Malang Dalam Menyelesaikan Skripsi." Universitas Islam Negeri Maulana Malik Ibrahim Malang.

Utami, Isiya, B., Hardjono, and A.K. Nugraha. 2014. “(2014). Hubungan Antara Optimisme Dengan Adversity Quotient Pada Mahasiswa Program Studi Psikologi Fakultas Kedokteran UNS Yang Mengerjakan Skripsi. Candrajiwa, ." Jurnal Ilmiah Psikologi 2 (5). 